\title{
PROPORÇÃO SEXUAL DE MACROBRACHIUM AMAZONICUM (HELLER, 1862) (DECAPODA: PALAEMONIDAE) À JUSANTE DA USINA HIDRELÉTRICA ÁGUA VERMELHA, SITUADA NO RIO GRANDE (ITURAMA-MG)
}

\author{
Andrade, L.S. ${ }^{1,}$; Carvalho, A.L.C. ${ }^{1}$; Costa, J.R.P. ${ }^{1}$; Carvalho, L.A.S. ${ }^{1}$; Castilho, R.C.C. ${ }^{\text {; }}$ Gomes, M.R.R.S. ${ }^{1}$ \\ Silva, M.A.G. ${ }^{1} \&$ Rodrigues, L.R. ${ }^{1}$ \\ ${ }^{1}$ Universidade Federal do Triângulo Mineiro (UFTM), Campus Iturama, Grupo de Ensino, Pesquisa e Extensão \\ em Animais Aquáticos (GEPEAA). \\ *Autor correspondente: andrades.nebecc@gmail.com
}

\begin{abstract}
O camarão Macrobrachium amazonicum tem ampla distribuição nas regiões tropicais e subtropicais. É uma espécie de crustáceo de água doce e também pode ser encontrado em algumas regiões salobras. Estudos sobre a proporção sexual dessa espécie são de grande importância, pois fornecem base para o acompanhamento da flutuação populacional. O objetivo desse trabalho foi avaliar a proporção sexual do camarão M. amazonicum à jusante da Usina Hidrelétrica de Água vermelha situada no Rio Grande, divisa entre os estados de São Paulo e Minas Gerais. Os animais foram coletados mensalmente, de Outubro/2017 a Março/2018, em 6 distintos pontos do Rio Grande, sendo o ponto 1 a mil metros e o ponto 6 a 4 mil metros da contenção do fluxo d'água. Uma peneira de saco, própria para camarões, foi arrastada três vezes, em giro de $180^{\circ}$ antes da colocação das armadilhas. Estas últimas foram amarradas à margem do rio e deixadas em espera por aproximadamente 6 horas. Os animais coletados foram individualizados por método de coleta, ponto e mês. Em laboratório, foram sexados e os dados obtidos foram planilhados e posteriormente analisados. Um total de 6455 animais foi coletado, sendo 4793 fêmeas, 1445 machos e 217 jovens. A proporção sexual encontrada foi de 1:0,3 (M:F) e diferiu significativamente da proporção sexual esperada de 1:1 (Binomial; $p<0,001$ ). Esse desvio ocorreu não somente na análise total dos dados, mas também nas comparações temporais $(p<0,001)$, por método $(p<0,001)$ e ponto de coleta $(p<0,001)$. Desvios na proporção mendeliana podem regular o tamanho de uma população, e quando esse desvio é para as fêmeas, podemos inferir que tal população esteja focando esforços em se manter em um ambiente que pode ser desfavorável para a continuação da espécie. Estudos como este auxiliam na estratégia de preservação do $M$. amazonicum na região e estimulam a inferência de hipóteses com relação à plasticidade reprodutiva da espécie.
\end{abstract}

Palavras-chave: sex-ratio, proporção mendeliana, plasticidade reprodutiva. 